\title{
FAVOURE RACOUCHOT SYNDROME WITH SCALP INVOLVEMENT: A CASE REPORT
}

\author{
Sabah Ibad, Moizza Tahir \\ Combined Military Hospital Multan/National University of Medical Sciences (NUMS) Pakistan
}

\begin{abstract}
Favoure racouchot syndrome is a solar elastotic disorder in which sun exposure or radiation causes skin damage leading to development of multiple open comedones. It usually affects the areas around the eyes, temples and the neck characterized by a diffuse yellowish hue. Presented here is a case of favoure racouchot syndrome involving scalp in a farmer. Scalp involvement has so far not been described as component of this syndrome. The eruption is usually bilaterally symmetrical. The exact pathophysiology remains unclear.
\end{abstract}

Keywords: Favoure racouchot syndrome, Scalp involvement, Solar elastotic disorder.

This is an Open Access article distributed under the terms of the Creative Commons Attribution License (http://creativecommons.org/licenses/by/4.0), which permits unrestricted use, distribution, and reproduction in any medium, provided the original work is properly cited.

\section{CASE REPORT}

A 60-year-old male, presented with deep grooves and multiple open and closed comedones with black central plug over periorbital, infraorbital and malar areas for 12 years. The involved skin was thickened. Facial lesions were symme- itching. He was farmer by occupation with prolonged sun-exposure since early childhood. He did not practice sun protection measures. He was hypertensive and was on lisinopril for 10 years. A clinical diagnosis of favoure racouchot syndrome (FRS) involving scalp was made.

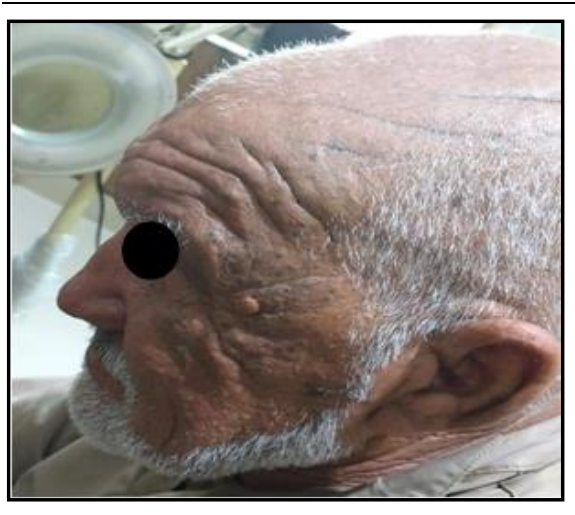

Figure-1: Periorbital comedones.

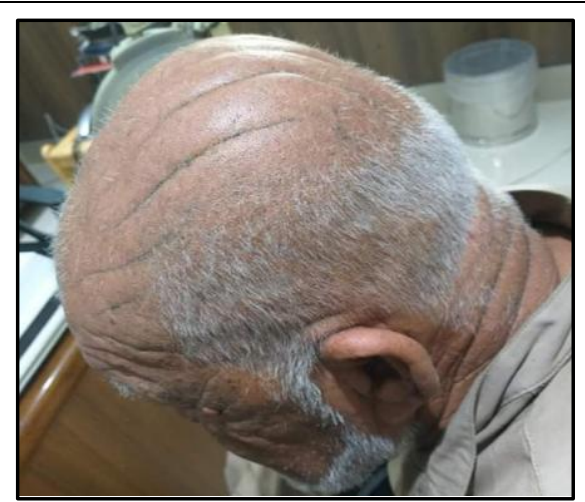

Figure-2: Scalp furrows studded with comedones.

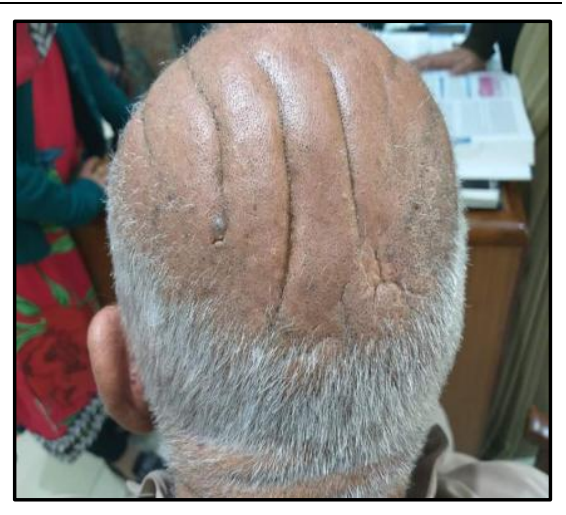

Figure-3: Scalp from back side. trical. Actinic damage and seborrheic keratosis was present. Skin tags were also seen around the eyes. He had androgenic alopecia. Scalp involvement was found to be progressive for three months. It was thrown into accentuated vertical furrows studded with black open comedones in a linear pattern. There was no history of pain or

Correspondence: Dr Sabah Ibad, Postgraduate Trainee, Combined Military Hospital, Multan Pakistan

Received: 18 Nov 2019; revised received: 17 Aug 2020; accepted: 21 Aug 2020

\section{DISCUSSION}

FRS is also known as senile or solar comedones, and nodular elastosis with cysts and comedones. Favoure and Racouchot described in this condition in 1951. Clinically, this syndrome presents with large, open comedones, deep wrinkles and furrows on atrophic skin. Temporal and periorbital areas of the face are commonly involved ${ }^{1}$. Chronic UV exposure, cigarette smoking and ionizing radiations are common etiological factors 2,3 . 
Rarely FRS has been described in the neck, forearms and post auricular regions.

The comedones of FRS are symmetrical and non-inflammatory in contrast to acne vulgaris. Asymmetrical involvement of face may be seen due to marked sun exposure to that area; as in case of drivers 4 . The pigmented skin seems to be less predisposed to sun damage than white skin. FRS is a clinical diagnosis and biopsy is rarely required ${ }^{5}$ Histopathology demonstrates open and closed comedones in this disease ${ }^{6}$. There is orthokeratotic and acanthotic epidermis. Dilated follicles and large cysts are seen in the middle and lower dermis. Upper dermis shows focal elastosis with extensive degeneration and basophilic fragmentation of collagen bund-les7. Topical retinoids (Tazarotene) have shown to be the most effective treatment of FRS8. Other options include mechanical removal, dermabra-sion, pulsed carbon dioxide laser and surgical removal ${ }^{9}$.

Differential diagnosis of scalp thickness in middle age group includes cutaneous mucinosis, chronic actinic dermatitis and cutis verticis gyrata. However in cutaneous mucinosis, skin is indurated and may have oozing of mucin. There are no open comedones ${ }^{10}$. Chronic Actinic dermatitis is associated with erythroderma, the background skin is lichenified ${ }^{11}$. In cutis veriticis gyrata scalp is thrown into folds but scalp lacks open comedones ${ }^{12}$.
Scalp involvement in FRS has not been documented earlier in published literature. We describe this case of scalp involvement as component of FRS.

\section{CONFLICT OF INTEREST}

This study has no conflict of interest to be declared by any author.

\section{REFERENCES}

1. Kulkarni V. Favre-Racouchot syndrome. Indian J Dermatol Venereol Leprol 1991; 57(5): 244-45.

2. Khouna A, Zerrouki N, Dikhaye S. An Unusual Association of Favre and Racouchot Syndrome with Basal Cell Carcinomas of the Face. Med Care Res Rev 2018; 2(6): 1-2.

3. Sandra V, Michael M, Sonja M, Thomas R, Joseph S. Unilateral Favre-Racouchot Disease: evidence for the etiological role of chronic solar damage. Dermatol Online J 2013; 226(1): 32-34.

4. Paganelli A, Mandel VD, Kaleci S, Pellacani G. Favre Racouchot disease: systematic review and possible therapeutic strategies. J Eur Acad Dermatol Venereol 2018; 33(1): 32-41.

5. Sidharth S, Rahul A, Namrata C, Uday K. Favre-Racouchot syndrome. Indian Dermatol Online J 2014; 5(6): 128-29.

6. Sánchez-Yus E, del Río E, Simón P. The histopathology of Closed and open comedones of Favre-Racouchot disease. Arch Dermatol 1997; 133(6): 743-45.

7. Fernanda C, Sadamitsu N, Gabrielle A. Actinic comedonal plaque-variant of Favre-Racouchotsyndrome: report of two cases. An Bras Dermatol 2015; 90(3): S185-87.

8. Efstathios R, Evmorfia K, Constantinos V. Successful treatment of favre-racouchot disease with $0.05 \%$ tazarotene gel. J Am Med Assoc 2007; 143(6): 810-12.

9. Ricardo D, García S, Iraida G. Occupational favre racouchot syndrome. J Gen Fam Med 2017 Dec; 18(6): 454-55.

10. Marie L, Josh L, Stephen P. Follicular mucinosis. Indian Dermatol Online J 2013; 4(4): 333-35.

11. Somani V. Chronic actinic dermatitis- A study of clinical features. Indian J Dermatol Venereol Leprol 2005; 71(6): 409-13.

12. Chutintorn S, Chadpraorn N. Bulldog scalp. Clev Clin J Med 2016; 83(2): 90-91. 